\title{
SKULLS ON THE ROAD - HISTORICAL TRACES OF ANATOMICAL CONNECTIONS BETWEEN ERLANGEN AND TARTU/DORPAT
}

\author{
Tim S. Goldmann ${ }^{1,2}$, Michael Scholz ${ }^{1}$, Fritz Dross ${ }^{2}$ \\ ${ }^{1}$ Institute of Functional and Clinical Anatomy, \\ Friedrich-Alexander-Universität Erlangen-Nürnberg, Erlangen, Germany \\ ${ }^{2}$ Institute for History and Ethics of Medicine, \\ Friedrich-Alexander-Universität Erlangen-Nürnberg, Erlangen, Germany
}

\begin{abstract}
The Chair for the History of Medicine at the Friedrich-Alexander-University of Erlangen-Nürnberg (FAU) is currently researching the provenance of human remains in the University Collections. Obviously, the by far largest number of those specimens is found in the Anatomical Collection, which is studied in close cooperation with the Institute of Functional and Clinical Anatomy a joint research project. Several specimens dating back to the time of Heinrich Friedrich Isenflamm (1771-1828) have been identified that went from Erlangen to Dorpat as well as others that came from Dorpat to Erlangen.
\end{abstract}

Keywords: anatomical collection; human remains; Heinrich Friedrich Isenflamm; Emil Woldemar Rosenberg; Erlangen; Dorpat (Tartu)

\section{THE ANATOMICAL COLLECTION AS A HISTORICAL STARTING POINT}

Since its foundation in 1743 , lectures on anatomy were given at the University of Erlangen. Among the five professors forming the Faculty of Medicine when the university was founded, Casimir Christoph Schmiedel (1718-1792) was responsible for botany and anatomy. To support his newly founded university, Margrave Friedrich decreed that all executed individuals of the Brandenburg-Bayreuth margraviate should be transferred to Erlangen for anatomical study. Initially, the chair of anatomy did not have its own building; therefore, 
Schmiedel complained about the "dismal and low rooms" [21: 24; 15 : 71] in which he had to perform the dissections. As the first discipline of the Medical Faculty, anatomy got its own extension to the university building in 1754 with an - albeit modest - Anatomical Theatre. In 1755 , the first anatomy prosector was hired in addition to the five professors of medicine. Since then, the Erlangen premises for anatomical study had two particular cabinets for storing anatomical specimens deriving from the postmortems. Other five cabinets were established for skeletons and bones. In 1809,

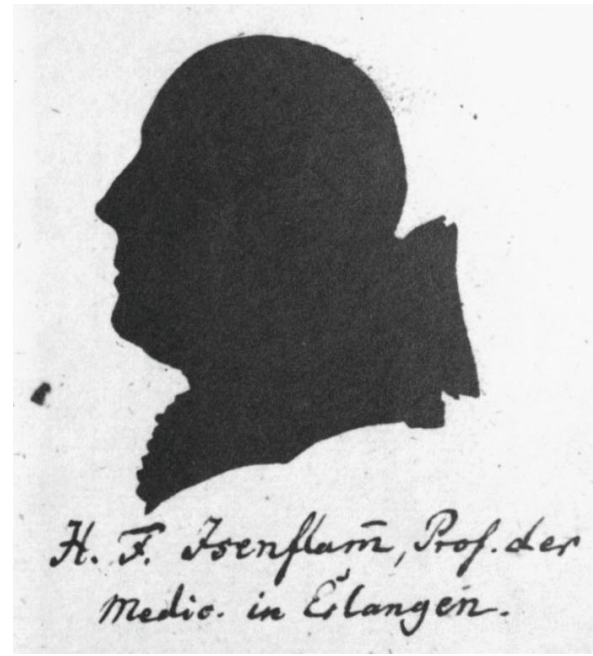

Figure 1. Undated silhoutte of Friedrich H. Isenflamm, Professor of Medicine in Erlangen (Stadtmuseum Nördlingen). during the liquidation of the Nuremberg Academy in Altdorf, which had been elevated to university status as early as in 1622, the 18th century specimens of the Nuremberg Academy in Altdorf were transferred to Erlangen. Further acquisitions of human remains by the Erlangen anatomist Friedrich Heinrich Loschge followed [9]. Today, the oldest reliably dated anatomical specimen in the Anatomical Collection is the so-called "cloverleaf skull" [18]. In 1788, Loschge reported in detail on the dissection of the corpse of a 38-day-old girl [13]. Born in Ansbach in 1755, Loschge came to Erlangen University in August 1784 as an associate professor of anatomy and prosector. From 1793-1824, he was head of the Erlangen Anatomical Theatre. He founded the AnatomicalPathological Collection in 1804 and managed the Botanical Garden of the University between 1811 and 1818 [12: 121; 7].

Under Loschge's leadership, Heinrich Friedrich Isenflamm, born in Erlangen in 1771, joined the anatomical institution in Erlangen. Initially, from 1791 onwards, he worked as prosector and assistant lecturer in anatomy. But already in the following year he became an associate professor and, in 1796, prosector at the Anatomical Theatre [12: 91f]. Even before the establishment of an Anatomical-Pathological Museum was approved in 1804, Heinrich Friedrich Isenflamm was offered a professorship at the University of Dorpat. Isenflamm accepted the offer and became full professor of anatomy, physiology and forensic medicine in Dorpat (today Tartu) in Estonia on 7 March 1803. Arriving in 


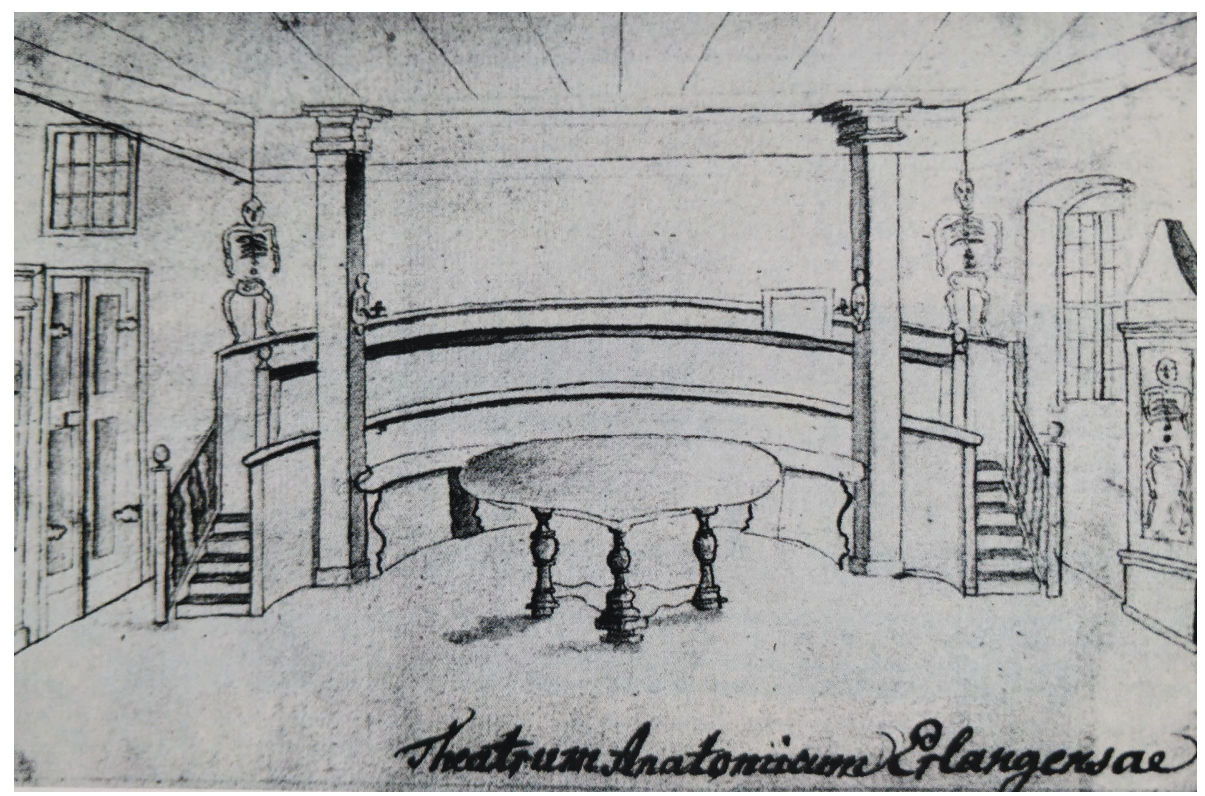

Figure 2. Drawing of the first "Theatrum Anatomicum Erlangensae" dated 1754 (Stadtarchiv Erlangen).

Dorpat in August 1803, he was at first shocked by the poor condition of the university and the building site from which "his" Institute of Anatomy would have to emerge. It reminded him of a "dog hole" [1: 93]. In 1805, the new Institute of Anatomy could be occupied, and the prosecture of the University of Dorpat was established [21: 15].

\section{ERLANGEN SPECIMENS ON THE JOURNEY TO DORPAT}

However, Isenflamm did not only bring his knowledge and skills from Erlangen with him but also a number of specimens which, in addition to those then produced in Dorpat, formed the basis for the anatomical collection at his new workplace. Isenflamm's Anatomische Untersuchungen (Anatomical Investigations) [10] describe a large number of anatomical specimens of human and animal origin that made their way from Erlangen to Dorpat and later on also the return. When, in November 1810, the anatomist asked for his release from Dorpat in order to return to Erlangen, the collection built up in Dorpat comprised a total of 869 specimens, 396 of which were phytological and 133 pathological, 338 were for comparative anatomy (zoological) and 2 were mummies [10: 321]. More than 150 specimens are individually listed in his research 
publications, and some are described in detail. The larger part of them derives from the collection in Dorpat.

According to Isenflamm, four significant provenances of the Dorpat collection, which was founded under his direction, can be distinguished. He brought some specimens with him from Erlangen, but not all of them were incorporated into the Dorpat collection: "The collection arose because I sold most of my specimens that I brought from Erlangen for the theatre (1), then I bought the collection from the deceased 'Leibchirurgus' [personal surgeon of the monarch] Lampe in Hannover (2), in addition a collection of mostly animals, birds, skeletons, etc. from the deceased Professor Rosenmüller in Leipzig" (3), and he produced several more himself in Dorpat [10: 321]. 25 specimens of this collection can reliably be assigned to their mentions in Isenflamm's publications.

\section{Isenflamm's Collection in Erlangen}

Among the specimens brought from Erlangen, two were specified. Regarding the skeleton of a 23-year-old person which shows an unfinished bone formation, Isenflamm remarks: "The skeleton is in Dorpat where I took it from Erlangen" [10: 76]. The corpse had been given for anatomical study in Erlangen as a suicide case. This skeleton is the only human specimen whose provenance can be assigned to Erlangen based on Isenflamm's Anatomical Investigations. Besides this one, he describes a quadrupedal chicken, which he brought from Erlangen [10:329]. However, research on the historical stock of the Anatomical Collection in Tartu should provide further evidence.

\section{The Collection of the Hannover Surgeon Johann Bodo Lampe}

Not much is known about the surgeon Lampe apart from his life dates - 17381802 - and his place of work - Hannover [20]. In particular, it is unclear whether Isenflamm and Lampe knew each other personally and on which occasion Isenflamm learned about Lampe's collection and how he ultimately acquired it. Nevertheless, the close connection between collecting of anatomical specimens and surgery that academics were known for here also becomes evident in the case of a non-academic surgeon. Isenflamm describes six specimens from Lampe's collection in more detail. First, a skull with special anatomical features. "On the head of a man who died raving, all braincase bones are thinner than usual, at the same time the face has some Jewish features visible in the malignant protuberance of the upper jaw, and curvature of the nasal bones" [10: 72]. 
In addition, he received "[an] aortic arch with four trunks" [10: 85]. Two of the skulls from Lampe's collection were exceptional because of the high age of the deceased and subsequently dissected persons. They derived from a couple of two 112-year-old individuals living " 80 years in marriage", toothless and "without traces of sutures on the inner but probably on the outer surface" [10: 322]. Furthermore, he describes a "male Negro of 5 months who, although his skin is not black but very dark, can be recognized as such via the formation of the head" [10:323f] and a "foetus extrauterinus which was carried for 5 years" [10:325]. Last, he mentions a skeleton of a mandrill coming from Lampe's collection [10: 327].

\section{The Collection of the Leipzig anatomist Johann Christian Rosenmüller}

After first studying medicine in Leipzig, Johann Christian Rosenmüller (17711820) was a student in Erlangen from 1792 to 1797. Here, he met Isenflamm before he received his doctorate in Leipzig in 1797 with a thesis about fossil animal bones [16; 17]. Until 1802, Rosenmüller went through a remarkable academic career in Leipzig as a lecturer, from 1802 as an associate professor of anatomy and surgery, then from 1804 as a full professor. Later, he held the office of the dean of the medical faculty several times and ascended to the rectorate of the university [3]. Together with Isenflamm, Rosenmüller edited two volumes of Beiträge für die Zergliederungskunst (Contributions to Anatomy) published by Tauchnitz in Leipzig in 1800 and 1803. Beyond the general characterization that the collection comprised "mostly animals, birds, skeletons, etc.", Isenflamm does not mention any details [10: 321].

\section{Specimens made or acquired in Dorpat}

With 17 of a total of 25 closely characterized specimens, the largest number originates from Dorpat or its surroundings, or alternatively from other donations. These include - presumably from a dissection in Dorpat - "head bones from a newborn girl" [10:26]. In addition, Isenflamm mentions three findings from Dorpat, which were uncovered by excavation work during the construction of the university library. These findings are a green molar with three roots and two green stained skulls, about one of which Isenflamm writes, "is of a girl of about 16 years. [...] On this head, there is still a large part of brown hair braided tightly, fastened by a ribbon in which one clearly saw metal threads around the head, but this ribbon fell apart soon. Such ribbons [...] are still used today as folk finery by Estonian women and girls" [10:33f.]. He gave this skull 
to the Dorpat collection. The other was a man's skull, which later - together with other skulls from Dorpat and its surroundings - travelled with Isenflamm first to Erlangen and from there to the Munich Academy of Sciences [10: 34f.]. In more detail, Isenflamm describes the case of an Estonian farmer whose dead body he received on April 13, 1806. Its congenital prolapsed and inverted urinary bladder was conspicuous. This "anatomically prepared specimen is with the collection of the Anatomical Theatre at Dorpat" [10: 97]. He also received the skull calvaria of a killed 11/2-year-old boy from "Kollegienrat" D. Kurzwich from Riga. Isenflamm himself dissected a 7-year-old girl killed in Dorpat, whose skull calvaria he also left to the collection [10: 127f.]. Another mandrill came to the collection after his death in Dorpat from "scrophula" in 1810 [10: 142]. After the dissection of a starved three-year-old boy from Dorpat, whose 8 th to 11 th vertebrae had been destroyed by bone erosion, this specimen also remained in Dorpat [10: 168]. Furthermore, Isenflamm received the specimen of a burst truncus coeliacus from a physician in Reval (Tallinn) [10: 208f].

From the dissection of the corpse of a Russian soldier in Dorpat in March 1810, he received another aortic arch with four trunks [10: 324]. "[A] postpartum monstrosity with one head, but 2 complete faces, 2 bodies thoracically fused, but each of which had 2 upper and 2 lower limbs [...] had been sent to the Theatre" by a Dorpat nobleman. Isenflamm skeletonized this "foetus hicoporeus" as he called it and stuffed it [10: 326]. From a clergyman in Livonia, he received a "bony laryngeal bladder of Beelzebub" [10: 327]. From Reval (Tallinn), a seal was delivered which he skeletonized, and a wild swan from the area of Lake Peipus [10: 328].

Isenflamm's anatomical network is again highlighted by a donation from Halle by the anatomist Ferdinand Justus Christian von Loder. Loder was born in Riga in 1753 and received his doctorate in 1777 after studying medicine in Göttingen. In the following year, he accepted a professorship in Jena where he established an extensive anatomical collection. In 1803, Loder moved to Halle. During the Napoleonic Wars, he settled in Moscow where he was appointed the personal consulting physician of the tsar and "Wirklicher Russischer Staatsrat" (Active Russian State Councillor) in 1810. Even then, he continued to collect anatomical specimens. His extensive collection of 4,243 specimens was acquired by Tsar Alexander I in 1818 for a respectable sum of 50,000 silver roubles and given to Moscow University [14: 7-10]. Loder bequeathed to Isenflamm the head of a 2-year-old boy with the anatomical presentation of the internal "auditory tools" on both sides [10: 322]. 
Finally, the two mummies which Isenflamm received from the tomb of Hatiar between Narva and Reval (Tallinn) have to be particularly emphasized. Both are also mentioned by Isenflamm's successor in Dorpat, Karl Friedrich Burdach, in his anatomical investigations of 1814 [6;10:316].

\section{DORPAT SPECIMENS ON THE JOURNEY TO ERLANGEN AND BEYOND}

Several specimens, however, travelled with Isenflamm not only from Erlangen to Dorpat but also from Dorpat to Erlangen. In fact, in 1810 he took specimens from the Anatomical Collection he had established in Tartu back to Germany. Obviously, he considered them personal property not only of scientific but also of considerable monetary value.

A glimpse into this return trip may be offered by a list of 26 skulls of different geographical origin which he "had already collected in Erlangen and even more of them afterwards in Dorpat, and then again in Erlangen in 1815 when taking care of sick Russian soldiers" [10: 296]. Isenflamm apparently regarded the specimens obtained by dissecting the corpses of deceased foreign patients as his property. He sold these skulls as well as "a Chinese woman's modelled foot with shoe", "a shirt of seal intestines" and "a female bear skeleton 4 weeks old" to the Academy of Sciences in Munich [10:296]. The list of skulls differentiates between five "races": 21 "Caucasian" skulls, one "American", two "Mongolian", one "Malanian", and one "Ethiopian" skull [10: 299f].

Of these 26 skulls, eight are described in more detail regarding their origin. First, Isenflamm describes the skull of a "Chuvash" (1) [10: 251], who died in 1807 of dysentery and typhoid fever in the military hospital in Dorpat and was brought to Isenflamm's Anatomical Theatre [10: 254]. The skull of the "Tatar" (2) came from the hospital for Russian soldiers in Erlangen and belonged to a 27-year-old soldier from Simbirsk (Ulyanovsk) [10: 276]. The skull of a "Bashkir" (3) was given to Isenflamm by a military hospital doctor in Livonia. Presumably, this skull was also brought from Dorpat to Erlangen [10: 281]. Isenflamm received the skulls of an "American" (4) and a "Marquesan" (5) from "Hofrat" Karl Espenberg in Reval. In 1809, Isenflamm visited his fellow student Espenberg in Erlangen [10: 286, 289]. Espenberg had brought these skulls from his circumnavigation which he did together with Adam Johann von Krusenstern [8: 286]. Finally, the skull of an "Italian" (6) which had already been examined by Jacob Friedrich Isenflamm in Erlangen, and two skulls of "Swedes" (7 \& 8) from the Dorpat church crypt are described [19: 36; 10: 298f]. 
Of the 26 skulls, six were certainly brought from Dorpat and two of them were anatomically dissected in Erlangen.

Drawings of two of the skulls brought from Dorpat, the "Chuvash" (1) and the "Marquesan" (5), were made in Erlangen to add these illustrations to his publication. Afterwards Isenflamm sold them to the Munich Academy of Sciences as part of a considerably larger collection [11]. Their further whereabouts are unknown; it is only certain that the specimens are no longer in Munich. It cannot be excluded that Samuel Thomas von Sömmerring received them in Munich and integrated them later into his own collection in Giessen. This might be indicated by Isenflamm in the list of the sold skulls about the skull of the "Malanian race" [10:299]: "I have already given this head two years before to Geheimrath und Ritter von Sömmering" [10: 300]. Research on this is still pending.

Of particular interest, however, are four specimens still present in the Anatomical Collection of Erlangen which directly indicate the origin from Tartu. These are (1-3) three skeletons of Ornithorhynchus paradoxus Blum, i.e., platypuses, which were first described by Johann Friedrich Blumenbach (1752-1840) in Australia in 1800 [5]. They are in storage boxes on which the inventory numbers 1138, 1139 and 1140, their zoological designation as well as a stamp imprint "Vergl. anat. Inst. d. Univ. Dorpat" can be found. However, these specimens could not have been brought to Erlangen by Isenflamm, since the Institute for Embryology, Histology and Comparative Anatomy in Dorpat as stated on the stamp was founded as late as in 1876 under Emil Woldemar Rosenberg (1842-1925). [21: 118ff.].

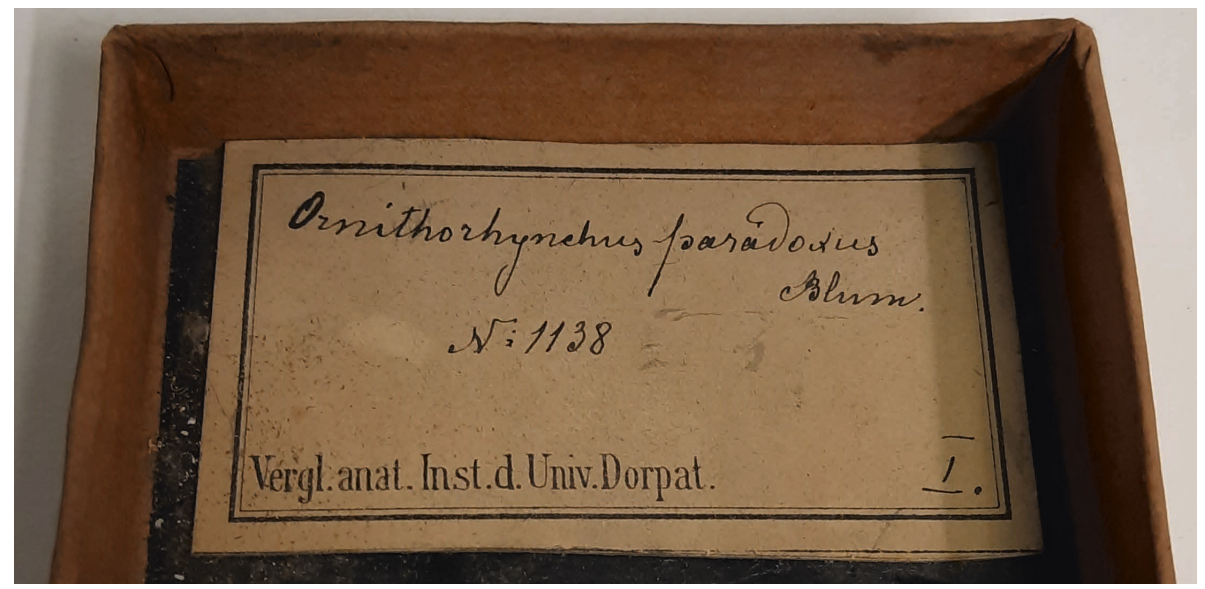

Figure 3. Box with the inscription "Vergl. anat. Inst. d. Univ. Dorpat" in which the platypus bones are kept. Photo by T. Goldmann. 
Another identifiable specimen in the Erlangen collection is (4) a skull with the imprint "Sammlung Rosenberg" (Rosenberg Collection). Whether this means the mentioned Emil Woldemar Rosenberg, professor in Dorpat from 1868 to 1888 [21: 18], his brother Alexander Anton Rosenberg, also professor in Dorpat from 1873 to 1898 [2: 1253f], or possibly even a third person, is still unclear. Alexander Rosenberg owned a large collection of skeletons which

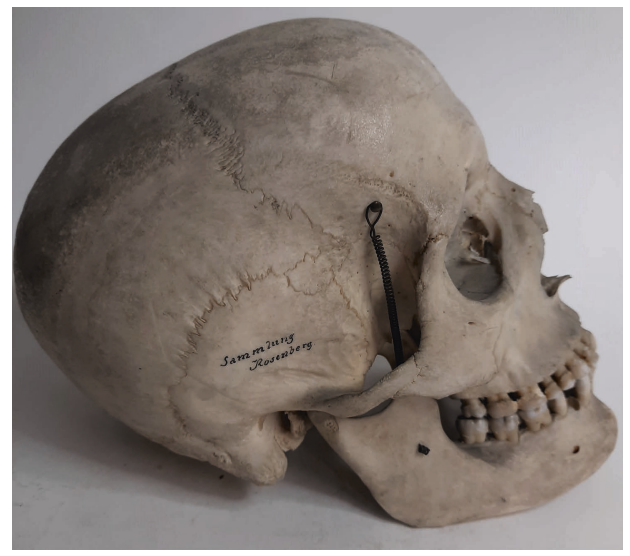

Figure 4. Unindentified skull with the inscription "Sammlung Rosenberg" in the Anatomical Collection Erlangen. Photo by T. Goldmann. included especially animal skeletons which makes him a possible candidate for the provenance of the platypus skeletons, too.

Emil Rosenberg, on the other hand, was the professor who founded the institute in Dorpat mentioned on the stamp. Nine pieces with Emil Rosenberg's signature surviving in Erlangen indicate a connection to the Erlangen Chair of Anatomy. These are eight books of Rosenberg's library and a contemporary photograph. Blumenbach's thesis De generis humani varietate nativa (1781) [4] was located in the cabinet display case directly next to the platypus skeletons and had been owned by the yet unknown Nuremberg physician Erdmann Peter August Hoffmann before it became part of the Rosenberg library. Zoologist Willy Kükenthal (1861-1922) personally dedicated his Vergleichendanatomische und entwicklungsgeschichtliche Untersuchungen an Walthieren (Jena 1889) to Rosenberg like the Belgian anatomist Hector Leboucq (18481934) did with his Résultats du Voyage du S. Y. Belgica en 1897-1887-1899 sous le commandement de A. De Gerlache de Gomery (Strasbourg 1904). However, it is still unknown how and when these pieces came to Erlangen. A closer connection might have existed between Albert Hasselwander, the Erlangen professor of anatomy from 1918 to 1948, who wrote the obituary for Rosenberg in Anatomischer Anzeiger and was acquainted with Rosenberg as a young student in Munich [8]. 


\section{CONCLUSION}

Even the above-mentioned brief examples of provenance research in Erlangen clearly show that the connections between the anatomical collections in Tartu and Erlangen are manifold. Very indicative of the elusive subject matter of this research is the fact that the human remains mentioned in Heinrich Friedrich Isenflamm's publications from the early 19th century, some of which are described quite precisely, can currently not be found as specimens because they were sold via various sales transactions to the Academy of Sciences in Munich and from there to another still unknown location. The human and animal remains in the Anatomical Collection of Erlangen which unequivocally refer to Tartu are to date not inventoried and - according to the current state of research - not published elsewhere; thus, their provenance must be further investigated. One of the fundamental problems of provenance research is that the two primary research paths cannot always be combined without difficulty. Due to incomplete inventories, the specimens that still exist today often cannot be dated precisely or traced back to certain individual persons, their circumstances of death and/or their anamnesis on the basis of dissection protocols. Besides the approach to physically investigate the specimens still available today, there is the additional approach of (re)searching historical literature for explicit mentions and remarks about former specimens. There if successful - references could be made to specimens that once existed and in some cases were described precisely regarding their provenance, but which, following multiple sales transactions and various losses, are no longer available as specimens or can no longer be reliably detected today.

It might be possible that other specimens of the Dorpat collection could be dated to the period of Isenflamm in the course of further provenance research and could possibly be assigned to the group of objects brought to Dorpat from Erlangen but not taken back afterwards. These include, in particular, a foetal skeleton which might be identical to one of those described by Isenflamm [10: 330]. Based on the platypus skeletons still existing in Erlangen as well as the skull from the "Sammlung Rosenberg", another connection with Dorpat independent of Isenflamm and clearly later - can be established which has to be investigated in the near future. Finally, however, a journey to and a visit of the present archives will become inevitable, in which hopefully, for example, purchase and sale of specimens might be determined from commercial inventories recording human remains as "goods" having commercial value. 


\section{REFERENCES}

1. Das erste Jahrzehnt der ehemaligen Universität Dorpat. Aus den Memoiren des Professors J. W. Krause. 1902. Baltische Monatsschrift, 53/54. http://hdl.handle. net/10062/62619

2. Biographic Directory of Estonian Scientists. https://www.ies.ee/ETBL/ETBL-III. pdf

3. Johann Christian Rosenmüller. In: Professorenkatalog der Universität Leipzig / Catalogus Professorum Lipsiensium. Lehrstuhl für Neuere und Neueste Geschichte, Historisches Seminar der Universität Leipzig. https://research. uni-leipzig.de/catalogus-professorum-lipsiensium/leipzig/Rosenmueller_1334/

4. Blumenbach J. F. (1781). De generis humani varietate nativa liber cum figuris aeri incisis. Göttingen: Vandenhoek. https://doi.org/10.18452/577.

5. Blumenbach J. F. (1800). Einige anatomische Bemerkungen über den Ornithorhynchus paradoxus aus Neu-Südwallis. Magazin für den neuesten Zustand der Naturkunde mit Rücksicht auf die dazu gehörigen Hülfswissenschaften, 2, 2, 284-291. Weimar.

6. Burdach K. F. (1814). Anatomische Untersuchungen: bezogen auf Naturwissenschaft und Heilkunst. Leipzig: Hartmann. http://mdz-nbn-resolving.de/ urn:nbn:de:bvb:12-bsb10330734-1

7. Fleischmann G. (1830). Geschichtlicher Ueberblick der Koenigl. anatomischen Anstalt zu Erlangen: von Errichtung der Universität bis auf gegenwärtige Zeit. Jung. Erlangen. http://mdz-nbn-resolving.de/urn:nbn:de:bvb:12-bsb10332715-6.

8. Hasselwander A. (1930). Nekrolog Emil Rosenberg. Anatomischer Anzeiger, 70, 81-107.

9. Holinski C. (2011). Friedrich Heinrich Loschge (1755-1840). Leben und Werk. Erlangen. https://nbn-resolving.org/urn:nbn:de:bvb:29-opus4-68651

10. Isenflamm H. F. (1822). Anatomische Untersuchungen. Erlangen: Heyder. http://mdz-nbn-resolving.de/urn:nbn:de:bvb:12-bsb10368680-6

11. Isenflamm H. F. (1813). Beschreibung einiger menschlichen Koepfe von verschiedenen Racen. Nürnberg: Schrag. http://mdz-nbn-resolving.de/ urn:nbn:de:bvb:12-bsb10220801-5

12. Ley A., Wittern R. (1999). Die Professoren und Dozenten der FriedrichAlexander-Universität Erlangen 1743-1960. Teil 2: Medizinische Fakultät. Im Auftr. d. Rektors, hg. v. Renate Wittern-Sterzel, Univ.-Bund Erlangen-Nürnberg e.V. https://nbn-resolving.org/urn:nbn:de:bvb:29-opus-20877

13. Loschge F. H. (1800). Beschreibung einiger Missbildungen an dem Kopfe und den Zungenbeinen eines Kindes. In: Beiträge für die Zergliederungskunst, Erster Band. Leipzig: Tauchnitz, 313-337. https://reader.digitale-sammlungen. de/de/fs1/object/display/bsb10368678_00335.html. 
14. Michler M., Müller-Dietz H. (1987). Loder, Justus Christian von. In: Neue Deutsche Biographie 15. Berlin: Duncker \& Humblot, 7-10. http://mdz-nbnresolving.de/urn:nbn:de:bvb:12-bsb00016333-7

15. Neuhuber W., Ruisinger M. M. (2007). Anatomische Sammlung. In: Andraschke U., Ruisinger M. M. (Hg.). Die Sammlungen der Universität ErlangenNürnberg. Erlangen: Friedrich-Alexander-Univ. Erlangen-Nürnberg, 71-82.

16. Rosenmüller J. C. (1794). Quaedam de ossibus fossilibus animalis cujusdam, historiam ejus et cognitionem accuratiorem illustrantia. Leipzig. http://hdl. handle.net/10831/26467

17. Rosenmüller J. C. (1796). Abbildungen und Beschreibungen merkwürdiger Höhlen in Muggendorf im Bayreuthischen Oberlande. Erlangen.

18. Ruisinger M. M. (2007). Kleeblattschädel. In: Die Sammlungen der Universität Erlangen-Nürnberg: Begleitband zur Ausstellung „Ausgepackt. Die Sammlungen der Universität Erlangen-Nürnberg“. Stadtmuseum Erlangen, 258.

19. Schmidt J. G. (1771). De difficili in observationes anatomicas epicrisi. Erlangen. http://mdz-nbn-resolving.de/urn:nbn:de:bvb:12-bsb11239238-0

20. Thielen H. (2002). Ziesenis, Maria Elisabeth, verh. Lampe. In: Hannoversches Biographisches Lexikon. Schlütersche Verlagsgesellschaft. Hannover, $398 f$.

21. Toomsalu M. (2006). Professors of the Old Anatomical Theatre of University of Tartu. Tartu: University of Tartu.

22. Wittern-Sterzel R. (2016). Vom Beginn der Ärzteausbildung zum Collegium Clinicum. In: Leven K-H., Plöger A. (Hg.). 200 Jahre Universitätsklinikum Erlangen. Köln: Böhlau, 23-31.

\section{Address for Correspondence}

Tim S. Goldmann

Institut für Geschichte und Ethik der Medizin

Friedrich-Alexander-Universität Erlangen-Nürnberg

Glücksstraße 10, 91054, Erlangen, Germany

E-mail: tim.s.goldmann@fau.de 